\title{
A TOKEN ECONOMY OF THE EARLY 19TH CENTURY
}

\section{IVOR STILITZ}

Precursors of behavior-modification methods appearing as early as ancient times are reported by Kazdin (1978, pp. 234-240). He gives particular attention to the schooling methods of Joseph Lancaster (1778-1838), and the case of Lancaster is considered in detail by Kazdin and Pulaski (1977). Lancaster promoted a system in which older pupils, the "monitors," were used to teach younger ones. This system made extensive use of reinforcers such as badges of merit and tokens that the pupils could exchange for prizes. Effective teaching was encouraged by rewarding the teacher when a pupil earned promotion to a higher class. Such methods were very influential in early 19th century England, the United States, and elsewhere.

An interesting variant on Lancaster's methods was developed by another Englishman, James Perry (1796-1843), whose approach is worth noting because of the centrality given to tokens in the teaching process and because each child was both pupil and teacher and received frequent reinforcement in both roles (Perry, 1823, Sections 18 and 19). Perry's ideal school consisted of 100 pupils with 10 children (a "class") to a row. Each child was responsible for teaching the child who sat behind him except for the top class, which was taught by the principal, and the bottom class, which had no teaching responsibilities. Perry's monitors were thus just one class ahead of their pupils. Perry's idea was that the teacher should not be too much in advance of his pupil so the teacher would not find the task boringly trivial. Teaching would also serve to reinforce the teacher's own learning and, in this respect, every

\footnotetext{
Address correspondence to Ivor Stilitz, 23 Rookfield Avenue, Muswell Hill, London N10 3TS, United Kingdom (e-mail: ivor.st@talktalk.net). doi: $10.1901 /$ jaba.2009.42-925
}

child would benefit. In Lancaster's scheme, by contrast, the teaching was done only by the ablest, most senior students, and each monitor taught a class of around 10 pupils simultaneously.

Perhaps the most interesting difference between Lancaster and Perry is that whereas Lancaster used the tokens as straightforward rewards, Perry used them in the context of an elaborate game-like system. Teachers gave pupils an initial stock of tokens in five denominations of $2,6,10,14$, and 18 units, respectively. At the end of each hour, the 10 pupils in each class stood in a semicircle in an aisle, and a pupil from the top class examined the pupils in the lower class. The teachers then ranked the students on the basis of the number of questions correctly answered, and the consequence for correct and incorrect question answering was receiving or losing tokens, respectively, as shown in Table 1.

The most extraordinary aspect of this accounting is that each student who received tokens handed over two thirds of their value (i.e., two tokens of the denomination in question) to his teacher. The teacher, in turn, handed over one of the two tokens he received (i.e., one third of the original sum) to his own teacher. A third of each loss was similarly refunded by the teacher and the teacher's teacher, respectively. It can be seen that, as well as teaching substantive subject matter, pupils were encouraged to teach other pupils how to instruct effectively. Hence, there was a motivational chain running through the school, with every student having a stake in the success and failure of other students. This dependence of individual reinforcement on the behavior of others has a parallel in such modern methods as the good behavior game described by Barrish, Saunders, and Wolf (1969). 
Table 1

The Rule for Giving and Receiving Tokens

\begin{tabular}{ccc}
\hline $\begin{array}{l}\text { The student } \\
\text { achieving rank }\end{array}$ & $\begin{array}{c}\text { Gives the student } \\
\text { achieving rank }\end{array}$ & $\begin{array}{c}3 \text { tokens of } \\
\text { denomination }\end{array}$ \\
\hline \hline 10 & 1 & 18 \\
9 & 2 & 14 \\
8 & 3 & 10 \\
7 & 4 & 6 \\
6 & 5 & 2 \\
\hline
\end{tabular}

Perry's pupils could exchange accumulated tokens for prizes of corresponding value at the end of each term or at other times decided by the principal. Perry (1823, Section 19, p. 23) states that pupils would enthusiastically work for tokens even if they could not be traded for prizes. The initial amount of tokens given to each pupil was recorded as a debt to the principal, and this debt might be increased during an accounting period if the pupil ran out of tokens and needed to be given more in order to participate (i.e., his net holding of tokens might be negative at the end of a term). The pupil would, nonetheless, receive a modest prize of value proportional to his token score. Thus, students worked not so much for a prize but for as valuable a prize as possible. Details of the scheme given by Perry could change. For example, gains and losses of tokens might be shared with a pupil's teacher but not the teacher's teacher (Perry, c1828, Section 1, p. 6), but he never deviated from the use of one-to-one teaching or from a token system more or less along the lines described.

As far as can be determined, Perry's work has not been previously reported in the educational or psychological literature. This is not entirely surprising, because he attempted to keep his methods secret except from prospective school principals who were prepared to pay to use them. Clients were required to sign a contract committing them to confidentiality (Perry, 1821, title page), and much of Perry's written guidance would have been opaque unless readers had already attended a series of lectures which he offered (The Times, 1824, p. 1).
Around the mid-1820s, Perry's main interest changed when he began experimenting with steel-nibbed pens as replacements for the traditional quills used by the children in his schools. In 1828 he formed a partnership with the Birmingham manufacturer Josiah Mason, and by the 1880s their firm, Perry \& Company, was the largest manufacturer of steel pens in the world (Stilitz, 2008). By that date, Perry the educationist seems to have fallen into obscurity.

\section{REFERENCES}

Barrish, H. H., Saunders, M., \& Wolf, M. M. (1969). Good behavior game: Effects of individual contingencies for group consequences on disruptive behavior in a classroom. Journal of Applied Behavior Analysis, 2, 119-124.

Kazdin, A. E. (1978). History of behavior modification. Baltimore: University Park Press.

Kazdin, A. E., \& Pulaski, J. L. (1977). Joseph Lancaster and behavior modification in education. Journal of the History of the Behavioral Sciences, 13, 261-266.

Perry, J. (1821). Outlines of a new system of education. Printed for the author by $H$. and R. Smith, Manchester. See title page. Location of text: British Library. Shelfmark 1502/26.

Perry, J. (1823). The principles of the Perryian system of education. 3 volumes. Printed for the author, 2, Cambridge Street, Manchester. 18th section: Organic Principles; 19th section: Principles of examination. Successive sections of the text are, as such, unnumbered. Page numbers begin afresh in each section. The sections in question are dated 1823. Location of text: British Library. Shelfmark 1490.e.1.

Perry, J. (c1828). Outlines of the course of lectures developing the principles and practices of the Perryian system as applied to the scholastic and private education of both sexes. London: printed for the author, 44, Hunter Street, Brunswick Square. Location of text: Institute of Education Library, University of London, England. Classmark: Damaged Books No. 94. Successive sections of the text are, as such, unnumbered. Page numbers begin afresh in each section.

Stilitz, I. (2008). The two careers of James Perry. Journal of the Writing Equipment Society. No. 82, Summer, Location of journal: National Art Library, Victoria and Albert Museum, London, England. Pressmark PP.32.L.

The Times. (1824). London, England, Saturday, December 18, p. 1. (Newspaper advertisement)

Received December 9, 2008

Final acceptance March 18, 2009

Action Editor, Chris Ninness 